\title{
Symbolic violence on social media: Covid-19 and the elderly
}

\author{
Violência simbólica nas redes sociais: Covid-19 e os idlosos \\ Violencia simbólica en las redes sociales: Covid-19 y los mayores
}

Elaine dos Santos Santana

ORCID: https://orcid.org/0000-0002-5550-8018 Universidade Estadual do Sudoeste da Bahia, Brasil

E-mail: elaine_137@hotmail.com Arianna Oliveira Santana Lopes ORCID: https://orcid.org/0000-0003-4990-8506 Faculdade Independente do Nordeste, Brasil E-mail: ariannasantana@ fainor.com.br

Alessandra Souza De Oliveira

ORCID: https://orcid.org/0000-0002-4459-1493

Faculdade Independente do Nordeste, Brasil

E-mail: alessandraoliveira@fainor.com.br

Nádia Cristina Moraes Sampaio Gobira

ORCID: https://orcid.org/0000-0002-5455-5058 Universidade Estadual do Sudoeste da Bahia, Brasil E-mail: ndiasampaio@yahoo.com.br

Layanne Christinne dos Passos Miguens

ORCID: https://orcid.org/0000-0002-6816-9916 Universidade Estadual do Sudoeste da Bahia, Brasil E-mail: layanne.miguens@ifma.edu.br

Luana Araújo Dos Reis

ORCID: https://orcid.org/0000-0002-9263-083X

Faculdade Independente do Nordeste, Brasil

E-mail: luareis@fainor.com.br

Luciana Araújo Dos Reis

ORCID: https://orcid.org/ 0000-0001-8416-7104 Universidade Estadual do Sudoeste da Bahia, Brasil

E-mail: lucianauesb@yahoo.com.br

\begin{abstract}
Objective: To analyze the symbolic violence related to COVID-19 and the elderly on social media. Methods: Qualitative research with a Brazilian case study as investigation strategy. The data collected for analysis were Brazilian memes published on the internet via Instagram social media. Such memes were randomly selected by searching the words "elderly" and "quarantine". In order to analyze as much material as possible, nineteen memes were selected. Content analysis, as proposed by Bardin, was used to investigate data supported by QSR NVivo® software. Results: Two categories for analysis emerged from the connection observed on the content of the memes selected: the elderly stigmatization and their autonomy denial. Final Considerations: The analysis of the study allowed interpreting that aged people have been constantly experiencing symbolic violence linked to COVID-19 on social media.
\end{abstract}

Keywords: Violence; Elderly; Discrimination; Social media; COVID-19.

\section{Resumo}

Objetivo: Analisar violência a simbólica nas redes sociais relacionadas ao caso da COVID-19 e os idosos. Metodologia: a pesquisa caracteriza-se por ser de natureza qualitativa, com a estratégia de investigação pautada no estudo de caso brasileiro. Os dados coletados para análise foram memes brasileiros publicados na internet na rede social Instagram. Os memes foram selecionados aleatoriamente a partir da busca pelas palavras "idoso" e "quarentena". Para analisar o máximo de material possível, dezenove memes foram selecionados. Os dados foram analisados por meio da Técnica de Análise de Conteúdo proposta por Bardin, com o auxílio do software QSR NVivo ®. Resultados: Nas conexões existentes entre os conteúdos dos memes selecionados para o estudo emergiram duas categorias de análise: estigmatização do idoso e retirada de autonomia do idoso. Considerações finais: A análise do estudo permitiu interpretar que os idosos vivenciam constantemente a violência simbólica vinculada ao COVID-19 nas redes sociais.

Palavras-chave: Violência; Idoso; Discriminação; Redes sociais; COVID-19. 


\begin{abstract}
Resumen
Objetivo: Analizar la violencia simbólica en las redes sociales relacionada con el caso del COVID-19 y el adulto mayor. Metodología: La investigación se caracteriza por ser de carácter cualitativo, con la estrategia de investigación guiada por el estudio de caso brasileño. Los datos recolectados para el análisis fueron memes brasileños publicados en Internet en la red social Instagram. Los memes se seleccionaron al azar a partir de la búsqueda de las palabras "anciano" y "cuarentena". Para analizar la mayor cantidad de material posible, se seleccionaron diecinueve memes. Los datos fueron analizados utilizando la Técnica de Análisis de Contenido propuesta por Bardin, con la ayuda del software QSR NVivo®. Resultados: De las conexiones existentes entre los contenidos de los memes seleccionados para el estudio, emergieron dos categorías de análisis: estigmatización del anciano y retiro de la autonomía del anciano. Consideraciones finales: El análisis del estudio permitió interpretar que las personas mayores experimentan constantemente la violencia simbólica vinculada al COVID-19 en las redes sociales.
\end{abstract}

Palabras clave: Violencia; Anciano; Discriminación; Redes sociales; COVID-19.

\title{
1. Introduction
}

Violence and human aging are intrinsic to humanity itself. There are high violence levels in urban areas happening in countless ways. Elderly abuse has increased singularly in the cities and among social classes (Poltronieri, Souza \& Ribeiro, 2019). Violence is the rupture of the victim's integrity in any form: physical, psychological, sexual, and/or moral (Guedes et al., 2015).

Thus, it is verified that there is a symbolic power that is exercised on a certain group of people or class. The contemporary society establishes a conception for aging which is forced upon the elderly themselves. Therefore, language is disguised into notions that rule the idea of growing old and its complexities (Dias, Azevedo, Silva \& Silva, 2018). The symbolic power is, in fact, that invisible power which can only be exercised with the complicity of those who do not want to know that they are subject to it or even that they exercise it (Bourdieu, 2012).

Symbolic violence is mean, cruel and inhuman because it is implicit in the speech, expressions and slangs, so it seems a natural element of social interaction. Usually, it comes disguised in jokes with apparent no intention to provoke humiliation. It may even go unnoticed. It may also be revealed on daily language, jokes made on the elderly fragility and presented as one more harmless expression, as if they were legitimate.

Therefore, language is indeed revealing. That is to say that language is free in memory, events and figures. It is marked by the society's historic, social and economic moments. Due to the inclusion of the elderly in the COVID-19 high risk groups, a current dissemination of memes using a humorous and stereotyped images of the elderly is on course. COVID-19 is a disease caused by the new coronavirus SARS-CoV-2, which presents clinical conditions that vary from asymptomatic infections to severe respiratory cases. The transmission occurs from a contaminated person to another by close contact such as handshakes, saliva droplets, sneeze, cough, phlegm or by touching contaminated objects or surfaces, so social distancing is the best way of prevention (Applegate \& Ouslander, 2020).

Consequently, the best way of protecting the elderly and immunocompromised is to keep apart from them till the risk is over. At this point, social distancing becomes important and its imposition to the elderly becomes evident on memes reverberating stereotypes and humor which end up disguising an oppressive and depreciating message regarding aged people (Pahor et al., 2020).

Internet memes are individual bits of information about a large range of topics presented by an image followed, or not, by a caption. Memes are widely shared electronically, and most of the times, they are humorous social comments (Williams, Oliver, Aumer \& Meyers, 2016). Thus, frequently, the sense of humor resides exactly in the perception of stereotypes and in their reinforcement. A joke's comicality is generally experienced by highlighting people's stereotyped characteristics, usually considered negative ones. Henceforth, symbolic violence can be unnoticed when elderly people are constantly infantilized with no right for autonomy (Wang et al., 2018). 
According to the Brazilian Senior Citizen Statute, aging is a personal right as well as its protection is a social right. Therefore, the Statute aims at guaranteeing protection, life and health to the aged as well as watch over their dignity by defending them from any inhuman, terrorizing, violent, vexing or embarrassing treatment. The law provides punishment for negligence, discrimination, violence, cruelty and oppression, by action or omission, towards the elderly (Brasil, 2003).

Article 4 of the Statute says that no senior citizen may be exposed to any form of negligence, discrimination, violence, cruelty or oppression. These actions will be punished by law, in the event of any harm to their rights, by action or omission. The same article determines that it is everyone's duty to prevent menace or the violation of the elderly's rights.

Bearing in mind what has been said above, studies on memes with the elderly during the OVID-19 pandemic are needed in order to discuss and uncover a current issue that comes from a seemingly harmless practice, but that can generate harm to this group at risk, and to propose strategies that avoid or minimize the effects of the spread of symbolic violence through the stigma and negative stereotypes of old age on social media.

A period of social distancing may bring up feelings of loneliness, stress, anxiety, sadness and depression for aged people. Such feelings can be accentuated due to the dissemination of symbolic violence on social medias and get them overwhelmed by emotions causing risks to their mental health and, consequently, their quality of life. In this perspective, the present study aims to analyze the symbolic violence related to COVID-19 and the elderly on social media.

\section{Methodology}

This research respected the copyright of the studies according to the decree $N^{\circ} 8,469 / 2015$ and the protection offered by CEP/CONEP for studies with analysis of secondary data, which aim at the production from already elaborated materials, contributing culturally to all, analytically, without the approval of the Research Ethics Committee.

Based on our goals, we propose a qualitative research through the presentation of a case study in Brazil, that is: an empiric investigation that examines a contemporary phenomenon in its real-life context, especially when the limits between the phenomenon and the context are not clearly defined (Silva, Castro-Silva \& Moura, 2018). SRQR guidelines were followed.

The data analyzed were memes shared by Brazilian profiles, published on the internet on the social networks Instagram. Instagram was the social network selected for allowing an easy search of memes through the explore tool. Data was selected by searching on Instagram using the keywords "quarentena" (quarantine), "idoso" (elderly) and "idoso teimoso" (stubborn old man).

To fulfill the objective, we considered as inclusion criteria: memes with mention of elderly people during the quarantine imposed by COVID-19 and that had been published between March and April 2020. The exclusion criterion established was: memes that mention any topic that don't be the elderly. Nineteen memes were identified for analysis, eight of which were images and the others in which they were videos.

After selecting the memes, the process was to transcribe the material completely, either by describing the images or the content of the videos. The data analysis was based on Content Analysis proposed by Bardin, and supported by QSR NVivo (B) software (QRS International, 2015).

The content analysis points to a set of techniques that search for indications which allow inference of knowledge related to the condition of production/reception of the messages. This search uses systematic procedures and aims at describing the images content. Bardin (2016) establishes three steps on the phase of planning and content analysis: (1) preanalysis, (2) material exploration, and (3) result processing.

Pre-analysis is the first step of planning a content analysis. For this study, the researchers selected memes to analyze, created research questions and hypothesis. The second step is to explore the material which requires the longest time for the 
research. The researchers codified the data and grouped them in unities. Finally, the third step is the result processing inference and interpretation. On this step, the researchers confronted the results with the theory turning them into meaningful analysis.

QSR NVivo ${ }^{\circledR}$ software was used as a tool to assist data restructuring by arranging the information into word clouds, highlighting the ones that were mentioned more frequently on the memes and their possible associations. This software's interface is based on Microsoft's guidelines, so it is easier to use it because it is familiar. The researcher starts the data arrangement process by grouping the texts/audios/images/videos into "nodes" which are organized in folders, establishing a hierarchy for the project. The "nodes" work as variables which gather descriptive information from the text, allowing tendencies identification. All researchers participated in the data collection process and contributed to their analysis and interpretation.

\section{Results}

The analysis of the selected memes identified the expressions "não" (not), "casa" (home), "véio" (granny) and "vou" (I am going to). It shows that these are the most important expressions present on the memes. They instantly announce the symbolic violence in corpus under analysis (Table 1).

Table 1. Top 4 most frequent words on memes about elderly people and COVID-19. Vitoria da Conquista/BA, 2020

\begin{tabular}{lccc}
\hline Word & Characters & Counting & $\begin{array}{l}\text { Weighted } \\
\text { percentage (\%) }\end{array}$ \\
\hline Não (Not) & 3 & 38 & 004 \\
Casa (Home) & 4 & 25 & 002 \\
Véio (Granny) & 5 & 22 & 002 \\
Idoso (Elderly) & 5 & 16 & 002 \\
\hline
\end{tabular}

Source: Authors.

Based on the connections among the content of these memes selected for the study, two categories for analysis emerged: stigmatization of the elderly and the denial of their autonomy.

\section{Category 1 - Stigmatization of the Elderly}

The most stigmatized message replied and reinforced by memes has been the idea of the stubborn, non-collaborative, insistent, overcritical old people. They also support the image of aged people who resist accepting the need to stay home during the pandemic and recklessly expose themselves to a COVID-19 infection by wandering on the streets unable of thinking about the current situation and the imminent risk of contamination.

There is also the presence of stigmatization strategies, built through discourse mediated by social media. The most frequent words in memes were: "não" (not), "véio" (granny), "casa" (home), "caminhão" (truck), "idoso" (elderly), "pessoa" (person) and "cata" (catcher), thus revealing a strong correspondence with symbolic violence. 


\section{Category 2. Denial of the Elderly's Autonomy}

The symbolic violence characterized in memes about COVID-19 and the elderly corresponds to all forms of contempt, prejudice and discrimination that may lead to sadness, isolation, loneliness, mental suffering and, often, depression. Violence is revealed in the words: "chave" (key); "portão" (Gate) and "presa" (locked)

\section{Discussion}

Symbolic violence plays an important role on the propagation of stereotypes and social stigmas. Social stigmas are the features and attributes that may cause someone to be criticized or marginalized by society (Yan, Chan \& Tiwari, 2015).

The stigma is, then, a feature labeled as «negative» by a group that establishes the identity of others, who are not able to free themselves from it. It can also be perceived on people who are not stigmatized. In other words, society ignores any other attributes that someone may have, focusing only on their stigmatized traits. This way, stigma classifies people into categories according to specificities that they are expected to have based on these negative stereotypes (Yon, RamiroGonzalez, Mikton, Huber \& Sethi, 2019).

In this study, the word "não" (not) is associated to denial or refusal and it characterizes the reduced autonomy and obedience noticed on the behavior of the aged during the pandemic. The expression "casa" (home) is associated to the social distancing as preventive sanitary measure that must be adopted by this group, in special. And the expression "véio" (granny) relates to the pejorative term used to refer and depreciate elderly people.

The elderly have been the most vulnerable group during the COVID-19 pandemic because they may present comorbidities which increase the death rate among this age group. As a result, there is a wider propagation of memes that infantilize ancient people and reinforce the need to take their autonomy apart from them during the pandemic (Suskind, Zhao, Boscardin, Smith \& Finlayson, 2020). Meaningful elements become clear even before they are used for any purpose in language. These memes have portrayed the elderly's capacity to adapt to the sanitary measures imposed by the authorities in an ironic, humoristic and stereotyped way (Bazza, 2016).

However, the authors of these memes are not taking into account the already precarious existence of many elderly people, especially those who live alone or depend on others to receive care. Neither has the emotional conditions faced by the elderly during the period of social detachment as a result of changing family dynamics. Some factors may cause stress, anxiety, depression, anger, emotional overdose, reduced quality of sleep and the decrease of physical and mental health caused by uncertainties related to COVID-19, the fear of being contaminated - especially because they belong to a high risk group -, the routine changes and reduced social and physical contact (Applegate \& Ouslander, 2020).

Stigma can load someone with attributes that influence external and internal relations. This can easily cause feelings of shame, anger, guilt and confusion (Cassétte et al., 2016).

Suddenly, all the autonomy of the elderly is stolen with the justification that they are incapable of acting with prudence and responsibility through the guidelines of social distancing, so they need strict control and vigilance. Therefore, such facts legitimize the idea that senior people are vulnerable and negatively characterized. In addition, this is a common idea of a group that considers itself immune to the virus because it does not belong to this age group and believes it has all the knowledge about the disease.

This discourse states that attributes related to young people may be considered positive (young people can go out because they are not part of COVID-19 high risk group), so they can control the autonomy of those who, in contrast, are negative and stigmatized (they are, indeed, included in the COVID-19 high risk group). Social media present a discourse about aging related to society historical roots. From this point of view, if we consider language as material system, and history as 
symbolic materiality, every discourse presented in these memes expresses the social view about aging and the elderly (Monteleone, Witter \& Gama, 2015).

Thus, many of such conceptions are implied in these memes. They spread aversion for old people once they usually associate aging to submission, unhealthiness, loneliness, loss of dignity and inaptitude. Such ideas end up supporting prejudice and stereotype which result inhasty and unjustified conclusions such as lack of discernment, unpleasant behaviour such as overcriticism and impatience. The elderly are treated similarly to something fragmented, perceived in spite of their objective conditions of existence. Old age representations are reflections of capitalism structures, processes and relations (Paulino, Siqueira \& Figueiredo, 2017).

In effect, symbolic power is welded by people who disseminate it and are symbolic agents of violence who impose the idea that a annoyed, stubborn old person needs to be restrained by others. In that way, violence is reproduced by a stigmatized discourse which reveals aging undesirable attributes. Besides, health status on social media, such as Instagram, which presents contexts, stability and invisible audience, leads to a continuous and quick spread of this social legitimization in a more explicit way, reaching different social groups (Fraga et al., 2017).

It is important to notice that in the memes under observation, humor seems to play a major role in the naturalization of violent discourse, reducing its impact and softening its offense. The use of the elderly figure in a humorous way to minimize symbolic violence, making it more acceptable, seems to be one of the most important strategies observed in the memes studied. Humor, delicate and joyful irony, helps not only with spreading the discourse, but also with reproducing and tolerating symbolic power. Even the subjugated group who, facing their fragility, naturalizes such actions due to their limited resistance and ability to stand up to the vivacity of the symbolic elements presented by the dominator (Dias, Azevedo, Silva \& Sousa, 2019).

The humorous funny old lady from memes, understood as form of speech, acts favoring the perpetuation of the symbolic violence noticed in these contents and on the interactions on Instagram. The representation of such discourses is woven into socio-historical relations and, at the same time, returns back to them (Fraga et a., 2017; Dias et al., 2019).

Verbal and non-verbal texts in memes seem to be impregnated with preconceptions and produce a personification of the elderly precisely because it associates the image of the elderly with the stigma of the headstrong, stubborn person unable to understand the current moment and, yet, dependent on people to be taken care of, often infantilized. All of these meanings are seen as a form of violence or aggression against the elderly, as the ideas created guide the view that society has about aging. Such figure portrays the social memory elaborated during the societies' historical processes. Thus, we can affirm that all discursive production that takes place under determined conditions of a moving situation circulates formulations previously stated. In other words, social memory is current, as it recalls elements that delimit ideas about aging from previous discourses for contemporary times (Velôso, Oliveira Filho, Henriques, Henriques \& Meira, 2017).

Under this view, the conceptions are crossed by pre-existing meanings. Memory is alive and every noticeable thing is related to it, so it is full of historical sense. This entire process is loaded with cultural and, above all, economic bias. In this way, an association is created between the elderly and all adjectives that have already been disseminated and naturalized in the language. However, to the elderly, there is no clear understanding of such an attitude. These discourses have movement and, there are often confrontations between what seems to be a joke and statements full of elements that deny aging. Therefore, ideology and the unconscious are materially linked (Monteleone et al., 2015).

Therefore, the symbolic violence in memes about COVID-19 in relation to the elderly is defined, at first, as an undercovered aggression, which, empowers and strengthens the violence. Therefore, it is essential to demystify the idea that any kind of violence can be, in some way, harmless. As for symbolic violence, Bourdieu (2012) highlights that it produces concrete consequences. "Treating violence against the elderly as something means embracing a set of facts and situations 
linked to the condition of growing old in the current world". Aging is a type of masked physical offense and as a consequence it is invisible and suppressed. This kind of violence has the effect of establishing the legitimacy of a decision discourse, from an agent or institution (Manouchehri, Ghorbi, Hosseini, Nasiri \& Karbakhsh, 2009).

Elderly people are the group that is most intimidated by the harmful effects of social distancing, since they are at greater risk for Coronavirus contamination and register the most serious outcomes and death due to infection (Applegate \& Ouslander, 2020; Suskind et al., 2020). The data reflect on the elderly's daily lives due to a high need of social distancing, although there is an initial resistance on the part of a minority to respect social distancing. The condition of growing old imposes many limitations on elderly's autonomy and freedom, and adding one more restriction to their daily lives may be very painful and difficult for them.

During the COVID-19 pandemic, there has been an increase in memes on social media, reporting the imposition of social distancing for the elderly in a stereotyped and humorous way, disrespecting their autonomy (their right to choose whether or not stay home has been disrespected as the use of railings, padlocks and granny's catchers are suggested). Autonomy is a central aspect of healthy aging, and promoting aged people the right to self-determination, maintaining their dignity, integrity and freedom of choice is fundamental for their quality of life promotion (Brasil, 2003).

Under the perspective of silent and subtle violence, Simone de Beauvoir (Beauvoir, 2018), in her work "The Coming of Age", recognizes and explains aspects of undercovered violence, imposed and perpetuated by contemporary society that, as time goes by, has been building stereotypes and images of old age, declared and imposed as "normal". This thematization of subtle or hidden silent violence was accentuated by the pandemic of COVID-19 in memes posted on social networks, unveiling a long-standing investigation path in contemporary society: symbolic violence against the elderly.

Violence against the elderly is an important public health problem which has followed the growth of this population, causing physical and mental illness (Poltronieri et al., 2019, Bourdieu, 2012). The undercovered, subtle, disguised violence, against the elderly in the COVID-19 memes, expressed while imposing social distancing and legitimized in the discourse of caring and well-being, has been clearer as the epidemic advances. The symbolic violence of memes attacks the elderly's autonomy, and they are generally practiced disguised as a wish for well-being and good care. Such attacks, little by little, deprive elderly's identities, possibly causing a silent revolt and keeping them from having emancipatory attitudes.

Concretely, with the forced social distancing suggested in memes, plots are created around the elderly that immobilize them, preventing them from exercising citizenship in full use of their reason and lucidity, since being aged does not mean losing the mental conditions to decide about your own life. Elderly people are denied the right to exercise their autonomy, no longer being able to experience routines, such as: sitting on their balcony, managing their money, and other daily activities. The elderly's right to feel useful within their limitations is denied, blocking them from exercising their autonomy, within their possibilities (Colussi et al., 2019, Yan et al., 2015).

The elderly are forced to isolate themselves from family and social decisions. After all, the elderly are thrown into the past, denied the present and kept from the future. It is the social death of elder people who, sometimes present an unstable emotional health, end up going into depressive processes that can culminate in biological death. Therefore, the subtle, silent violence expands and perpetuates itself (Beauvoir, 2018), re-updating stereotypes and (negative) images of aging, allowing us, at the same time, to foresee that violence is diverse and is practiced in many different ways other than physical or verbal aggression, sexual abuse, abandonment, financial abuse and negligence. This subtle violence is almost invisible to its own victims, because as Bourdieu claims (Bourdieu, 2012), it is based on a field of affective, intimate relationships, which end up allowing the domination.

Symbolic, soft, insensitive, and invisible violence to its own victims, is exercised, essentially, by the purely symbolic ways of communication and knowledge or, more precisely, ignorance, pain and judgment or, ultimately, feeling. 
This extraordinarily traditional social relationship also offers a unique opportunity to grasp the logic of domination, exercised in the name of a symbolic principle known and recognized either by the language dominant or dominated (or a way of speaking), a style of life (or a way of thinking, speaking or acting) and, more generally, a distinctive property, emblem or stigma.

The invisibility of the elder person as a human being who has rights and duties is a factor that directly contributes to this veiled and subtle violence in memes about COVID-19. The image of fragility, illness and dependence removes the elderly's recognition as a social, personal and even political citizen and puts them in the place of a social weight (Poltronieri et al., 2019, Dias et al., 2018). Violence, specifically against the elderly in memes about COVID-19, reflects a cultural sense of devaluation of the elderly built over time and perpetuated in the social memory that is anchored in the binomial aging-getting sick (Yon et al., 2019).

The study was developed on only one social media, Instagram. In this way, the scenario unveils the experience of a specific group in the network, pointing to the need to broaden the perspective of other social medias.

The prevention of symbolic violence involves a change in culture, in the concept of aging and in society's view of the elderly. Thus, in this moment of the COVID-19 pandemic, it is expected that this study will contribute to the adoption of strategies to confront symbolic violence in order to minimize the damage caused by the social distance necessary in this period. The role of health professionals in the health education process of the population is emphasized, demystifying possible misconceptions about the new SARS-CoV-2 coronavirus and which may result in the occurrence of some form of violence against the elderly.

Furthermore, the verification of symbolic violence perpetrated by memes on social media reinforces the understanding of violence against the elderly as a public health problem and the increasingly urgent need for campaigns to combat it that address respect for the elderly as a citizen. Faced with the new reality of communication, social media themselves can be vehicles for holding events, such as live broadcasts, which aim to inform and protect the elderly, alerting the population to the importance of accompanying them during the period of social distance, through physical and mental observation.

The creation and dissemination of strategies that address issues of how to deal with the isolation of the elderly aimed at family members and caregivers assist in this fight and allow rescue to the dignity of the elderly in times of pandemic, preparing them for the social transformations that COVID-19 imposed on the world.

In addition, violence against the elderly is a condition of compulsory notification and it is also up to the health professional to act in the process of deconstructing stereotypes that can result in violence.

\section{Conclusion}

This study analyzed the symbolic violence shared by Brazilian profiles on social media through memes related to COVID-19 and the elderly and demonstrated how this age group of the population experiences such violence in their daily lives, given that the idea of aging as a tragic and full of disabilities is rooted in the social imagination. The elderly represent the group most at risk for contamination by COVID-19 and, therefore, would not be recognized as a social category that deserves to exercise their rights and duties.

Thus, symbolic violence becomes common, especially with the elderly, and we can see when autonomy is removed from them through expressions, anecdotes, jokes and comparative phrases that diminish and vulgarize the image of the elderly in memes. 
Often, the recognition of violent acts can be difficult, as there is an internalization of expressions and behaviors as natural and inherent to aging. Therefore, it is necessary to reflect on the type of care that the elderly are being subjected to during the COVID-19 pandemic and, in parallel, to understand the arrests of ideologies, ethical and moral standards that fuel and disseminate symbolic violence against the elderly.

\section{References}

Applegate, W. B., \& Ouslander, J. G. (2020). COVID-19 presents high risk to older persons. J Am Geriatr Soc, 68(4), 681-689. 10.1111/jgs.16426 Bardin L. (2016). Análise de Conteúdo. Laurence Bardin; tradução Luís Antero Reto, Augusto Pinheiro. Edições 70.

Bazza, A.B. (2016). A constituição da subjetividade no discurso do idoso sobre si. Linguagem em (Dis)curso, 16(3), 449-464. https://doi.org/10.1590/19824017-160305-1416

Beauvoir S. A velhice. Maria Helena Franco Martins. (2a ed.), Nova Fronteira, 2018.

Bourdieu, P. (2012). A dominação masculina. (11a ed.). Bertrand Brasil.

Brasil. (2003). Lei $\mathrm{n}^{\mathrm{o}}$ 10.741, de $1^{\text {o }}$ de outubro de 2003. Dispõe sobre o Estatuto do Idoso e dá outras providências. Diário Oficial da União., http://www.planalto.gov.br/ccivil_03/leis/2003/L10.741.htm

Cassétte, J. B. et al. (2016). HIV/aids em idosos: estigmas, trabalho e formação em saúde. Revista Brasileira de Geriatria e Gerontologia, 19(5), 733744. https://doi.org/10.1590/1809-98232016019.150123

Colussi, E. L., Kuyawa, A., Marchi, A. C. B. D., \& Pichler, N. A. (2019). Percepções de idosos sobre envelhecimento e violência nas relações intrafamiliares. Revista Brasileira de Geriatria e Gerontologia, 22(4). https://doi.org/10.1590/1981-22562019022.190034

Dias, M. D. J. S., Azevedo, L. M. N., da Silva, L. C. N., \& de Sousa, F. T. L. (2019). Violência simbólica contra mulher idosa nas relações de gênero. Revista Interdisciplinar em Cultura e Sociedade, 4 (Espec), 481-491. http://www.periodicoseletronicos.ufma.br/index.php/ricultsociedade/article/view/10545/6146.

Fraga, S., et al. (2017). Lifetime abuse and quality of life among older people. Health Soc Work, 42(4), 215-222. 10.1093/hsw/hlx036

Guedes, D. T., et al. (2015). Socioeconomic status, social relations and domestic violence (DV) against elderly people in Canada, Albania, Colombia and Brazil. Archives of gerontology and geriatrics, 60(3), 492-500. 10.1016/j.archger.2015.01.010.

Manouchehri, H, et al (2009). Degree and types of domestic abuse in the elderly referring to parks of Tehran. Adv Nurs Midwifery, 18(63), 39-45 (Persian). $10.22037 /$ anm.v18i63.1182

Monteleone, T. V., Witter, C., \& Gama, E. F. (2019). Representação social de idosos: análise das imagens publicadas no discurso midiático. (2015) Estud. interdiscipl. envelhec. 20(3), 921-937. https://seer.ufrgs.br/index.php/RevEnvelhecer/article/view/48330/36695

Paulino, L. F., et al. (2017). Subjetivação do idoso em materiais de educação/comunicação em saúde: uma análise na perspectiva foucaultiana. Saúde e Sociedade, 26(4), 943-957. https://doi.org/10.1590/s0104-12902017161399

Pahor, M., et al. (2020). Impact and Lessons From the Lifestyle Interventions and Independence for Elders (LIFE) clinical trials of physical activity to prevent mobility disability. Journal of the American Geriatrics Society, 68(4), 872-881. 10.1111/jgs.16365

Poltronieri, B. C., Souza, E. R. de, \& Ribeiro, A. P. (2019). Violência no cuidado em instituições de longa permanência para idosos no Rio de Janeiro: percepções de gestores e profissionais. Saúde e Sociedade, 28(2), 215-226. https://doi.org/10.1590/s0104-12902019180202

QRS International. (2015). NVivo 11 for Windows - Getting Started Guide. Doncaster, AUS: QSR International Pty Ltd.

Ruiz-Pérez, I., et al. (2018) Intimate partner violence and mental disorders: co-occurrence and gender differences in a large cross-sectional population based study in Spain. J Affect Disord; 229: 69-78. 10.1016/j.jad.2017.12.032

Silva, A. da, Castro-Silva, C. R, \& Moura, L. de. (2018). Pesquisa qualitativa em saúde: percursos e percalços da formação para pesquisadores iniciantes. Saúde e Sociedade, 27(2), 632-645. https://doi.org/10.1590/s0104-12902018172700

Suskind, A. M., et al. (2020). Time Spent Away from Home in the Year Following High-Risk Cancer Surgery in Older Adults. $J$ Am Geriatr Soc. Mar;68(3), 505-510. 10.1111/jgs. 16344

Velôso, T. M. G., et al. (2017). Descrições sobre a velhice: a identidade terceira idade em depoimentos de idosos. Estud. interdiscipl. envelhec. 2017, 22(3), 79-97, 2017. Disponível em: https://seer.ufrgs.br/RevEnvelhecer/article/view/63898/49691

Wang, F., \& Meng, et al. (2018). Elder abuse and its impact on quality of life in nursing homes in China. Archives of gerontology and geriatrics, 78, 155-159. 10.1016/j.archger.2018.06.011

Williams, A., Oliver, C., Aumer, K., \& Meyers, C. (2016). Racial microaggressions and perceptions of Internet memes. Computers in Human Behavior, 63, 424-432. 10.1016/j.chb.2016.05.067 
Research, Society and Development, v. 10, n. 5, e37010515060, 2021

(CC BY 4.0) | ISSN 2525-3409 | DOI: http://dx.doi.org/10.33448/rsd-v10i5.15060

Yan, E., Chan, K. L., \& Tiwari A. (2015). A systematic review of prevalence and risk factors for elder abuse in Asia. Trauma Violence Abuse, 16(2):199-219. $10.1177 / 1524838014555033$

Yon, Y, et al. (2019). The prevalence of elder abuse in institutional settings: a systematic review and meta-analysis. Eur J Public Health, 29(1), 58-67. 10.1093/eurpub/cky093 